\title{
Invading Mnemiopsis leidyi as a potential threat to Baltic fish
}

\author{
Holger Haslob ${ }^{1, *}$, Catriona Clemmesen ${ }^{1}$, Matthias Schaber ${ }^{1}$, Hans-Harald Hinrichsen ${ }^{1}$, \\ Jörn Oliver Schmidt ${ }^{1}$, Rüdiger Voss ${ }^{1}$, Gerd Kraus ${ }^{2}$, Friedrich W. Köster ${ }^{2}$ \\ ${ }^{1}$ Leibniz Institute of Marine Sciences, Düsternbrookerweg 20, 24105 Kiel, Germany \\ ${ }^{2}$ Danish Institute of Fisheries Research, Charlottenlund Castle, 2920 Charlottenlund, Denmark
}

\begin{abstract}
The occurrence of the ctenophore Mnemiopsis leidyi as a new invasive species in the Baltic Sea and the potential consequences for fish stock recruitment was investigated in spring 2007. The study focused on the Bornholm Basin, which serves as the major spawning ground for cod and sprat, the commercially most important fish stocks in the Baltic. The distribution pattern of M. leidyi revealed a substantial overlap with cod eggs. The observed predation of $M$. leidyi on eggs has the potential to alter the recruitment success of cod, which is the top predator in the system and, thus, to change the Baltic food-web structure.
\end{abstract}

KEY WORDS: Invasive species $\cdot$ Cod recruitment $\cdot$ Baltic food web

\section{INTRODUCTION}

The introduction of new species can be harmful to a marine ecosystem, with semi-enclosed seas being more sensitive to impacts than the open sea (Caddy 1993). The lobate ctenophore Mnemiopsis leidyi has been shown to be a dangerous invader of the Black Sea, feeding intensively on early life stages of commercially important fish species, not only deteriorating recruitment success of fish stocks and the viability of the fishery, but also altering the structure and functioning of the entire ecosystem (Shiganova et al. 2001, Kideys 2002).

In the Baltic Sea, this species was first recorded in the shallow Kiel Bight (western Baltic) in October 2006 - probably introduced via ballast water (Javidpour et al. 2006). Results from drift model studies suggested that advection will further propagate gelatinous plankton from the western Baltic into the deep basins of the Baltic Sea (Barz et al. 2006). Processes transport- ing particles from western parts of the Baltic to eastern parts are controlled by variations in atmospheric forcing conditions (Hinrichsen et al. 2001). As predicted, in 2007 Mnemiopsis leidyi were recorded in the Bornholm Basin (Kube et al. 2007), thereby invading important spawning grounds of cod and sprat (Köster et al. 2005).

Due to its hydrographic conditions, the Bornholm Basin is currently the only area in which successful spawning of the eastern Baltic cod stock occurs regularly (Köster et al. 2005). As a consequence, replenishment of this heavily fished population depends solely on this area, while sprat is also able to reproduce successfully in the more eastern basins.

\section{MATERIALS AND METHODS}

Mnemiopsis leidyi were collected during a cruise with the German RV 'Alkor' in May 2007 as part of a 
standard survey designed to update time series on ichthyoplankton abundance and distribution in the Bornholm Basin of the Baltic Sea. The analysis conducted on $M$. leidyi distribution was an ad hoc approach, as it was the first time this species occurred in high abundances in the Central Baltic Sea. Sampling covered the entire Bornholm Basin (11800 km²) on a 45-station grid with approximately 10 nautical mile grid-point distances. The gear was a Bongo net (60 cm diameter) equipped with 335 and $500 \mu \mathrm{m}$ mesh sizes towed in a double oblique haul integrating the entire water column down to $2 \mathrm{~m}$ above the bottom. Species counts were standardised to $1 \mathrm{~m}^{2}$ surface area by the volume of water filtered and the maximum depth of the tow. The vertical distribution of $M$. leidyi and ichthyoplankton was resolved in $5 \mathrm{~m}$ steps by multiple casts on one station $\left(54^{\circ} 17.5^{\prime} \mathrm{N}, 15^{\circ} 45.0^{\prime} \mathrm{E}\right)$ in the central Bornholm Basin with an opening/closing multinet (mesh size $335 \mu \mathrm{m}$ ). Corresponding ambient hydrographic conditions (salinity, temperature, oxygen concentration) were recorded at each station. Specimens of $M$. leidyi were counted and measured directly on board. Ichthyoplankton samples were fixed with a $4 \%$ formaldehyde seawater solution and identified and counted in the laboratory using a stereo microscope.

To estimate the vertical overlap of Mnemiopsis leidyi as potential predator and fish eggs as prey, a relative coefficient of overlap ( $C$ ) was calculated (Horn 1966). The coefficient is 0 when there is no overlap and 1 at identical distributions of predator and prey:

$$
C=2 \sum_{i=1}^{n}\left(A_{i} \times B_{i}\right) /\left(\sum_{i=1}^{n} A_{i}^{2}+\sum_{i=1}^{n} B_{i}^{2}\right)
$$

where $n$ is the number of depth strata covering the water column and $A$ and $B$ are the relative abundances of predator (M. leidyi) and prey (fish eggs) organisms per depth strata.

\section{RESULTS AND DISCUSSION}

The horizontal distribution of Mnemiopsis leidyi was restricted to areas deeper than the $60 \mathrm{~m}$ isobath, with highest abundances in the central basin $(>75 \mathrm{~m}$, Fig. 1A) where also the highest cod and sprat egg concentrations were found. M. leidyi occurred from 55 to $90 \mathrm{~m}$ depth covering a salinity range of 11 to $16 \mathrm{psu}$ (Fig. 1B). Highest numbers of individuals were found in the 70 to $75 \mathrm{~m}$ water layer. Fish eggs occurred in the same depth with sprat eggs slightly higher in the water column than cod eggs (Fig. 1C). M. leidyi sampled in the Bornholm Basin were found to feed on fish eggs (Fig. 1D). The vertical overlap coefficient with cod eggs (0.21) was more than 4 times higher than with sprat eggs (0.05), indicating a higher predation impact on cod eggs than on sprat eggs. If $M$. leidyi exerts a substantial predation pressure on fish eggs, thus removing a substantial portion of the daily egg production, the true overlap may even be higher than estimated here.

Due to the observed temporal and spatial overlap with cod eggs, Mnemiopsis leidyi should be considered a potentially important predator of cod. Data on clearance rate and digestive time of $M$. leidyi on anchovy eggs from the Chesapeake Bay have shown that both are dependent on prey density (Purcell et al. 2001). Thus, the predation pressure on cod and sprat eggs in the Baltic is likely to increase when eggs of both species concentrate in high abundances over a limited depth range caused by a strong density gradient. This scenario is frequently observed during phases of limited deep water renewal accompanied by low oxygen concentrations, which also negatively affect fish egg survival (Köster et al. 2005). Besides predation, $M$. leidyi can potentially influence fish recruitment via food competition with fish larvae, as $M$. leidyi has been shown to reduce the stocks of mesozooplankton considerably in other seas (Shiganova et al. 2001).

Due to its tolerance of variations in temperature and salinity (Harbison 2001), Mnemiopsis leidyi is expected to be capable of permanently occupying the brackish ecosystem of the Baltic Sea. It is also able to tolerate low oxygen concentrations in bottom water layers of the deep basins, characterized by relatively stable temperatures of 4 to $8^{\circ} \mathrm{C}$. Consistent with this expectation, $M$. leidyi successfully survived the 2006/2007 winter in the deep water of the Bornholm Basin (Kube et al. 2007). The last 2 decades were characterized by a marked increase of temperature in the Baltic (BALTEX 2006) that should generally favour the living conditions for $M$. leidyi. Rising temperatures will likely lead to an increase in $M$. leidyi egg production (Purcell et al. 2001) and thus an increase in biomass during spring and summer. However, studies on $M$. leidyi survival and reproduction under ambient environmental conditions in the Baltic Sea are necessary to prove this.

Our results suggest a negative impact from Mnemiopsis leidyi on cod, the commercially most important fish species in the Baltic. In contrast to the previously invaded ecosystems in Southeastern Europe, where mainly small pelagic fish were affected, in the central Baltic Sea the main predator, cod, is threatened. An aggravating factor is that the Eastern Baltic cod stock is already suffering from detrimental environmental conditions and overfishing. Potential control measures reviewed by Bilio \& Niermann (2004) for the Black Sea, i.e. the introduction of gelatinous predators such as Beroe ovata, are not promising for the Baltic Sea due to its extremely low salinity compared to the oceanic 

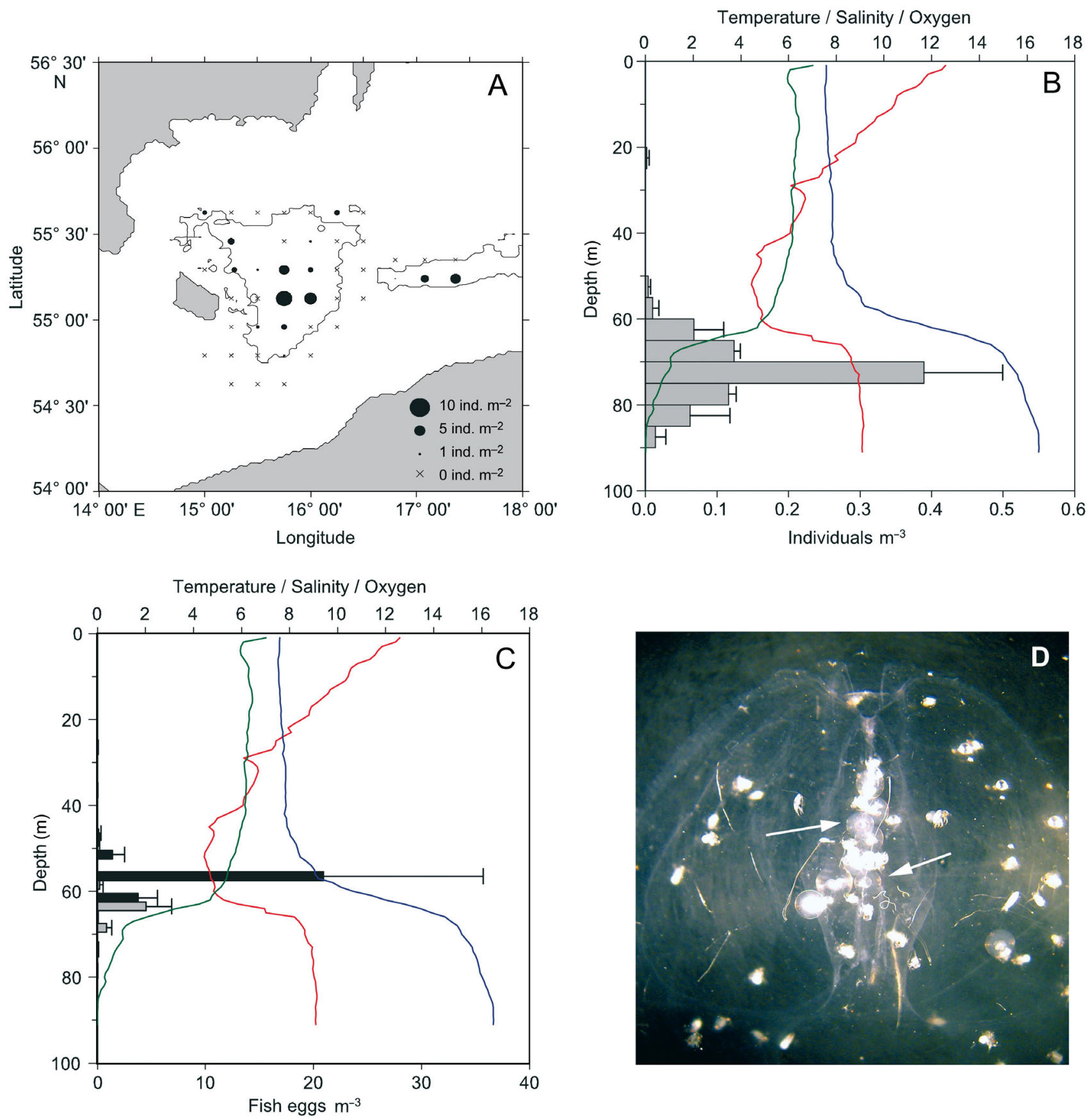

Fig. 1. Mnemiopsis leidyi. (A) Horizontal distribution (black dots) of M. leidyi in the Bornholm Basin and sampled stations with no occurrence of $M$. leidyi $(\times) .75 \mathrm{~m}$ depth isobath (black line). (B) Vertical distribution (grey bars; mean + SD) of $M$. leidyi in the Bornholm Basin. Temperature $\left({ }^{\circ} \mathrm{C}\right.$, red line), salinity (psu, blue line), and oxygen $\left(\mathrm{ml} \mathrm{l}^{-1}\right.$, green line). (C) Vertical distribution of cod eggs (grey bars; mean + SD) and sprat eggs (black bars; mean + SD). Temperature, salinity and oxygen as in (B). (D) Image of $M$. leidyi with fish eggs in the digestive tract (white arrows)

realm, which makes the Baltic Sea unsuitable as a habitat for many marine species. Moreover, this option could have unforeseeable negative consequences for the low diversity indigenous fauna. Presently, the most effective conservation measure for Baltic cod would be a conservative fisheries management.
In conclusion, Mnemiopsis leidyi has the potential to significantly alter the Baltic pelagic food web through predation on cod eggs as well as on zooplankton. This will have to be considered in future research concerning the ecosystem approach to management of the Baltic Sea and its living resources. 


\section{LITERATURE CITED}

BALTEX (2006) Assessment of climate change for the Baltic Sea Basin - The BACC Project. International Conference, Göteborg, Sweden, Available at: http://www.gkss.de/baltex/publications/PubNo_35/IBS\%20No35\%20BACC.pdf

Barz K, Hinrichsen HH, Hirche HJ (2006) Scyphozoa in the Bornholm Basin (central Baltic Sea): the role of advection. J Mar Syst 60:167-176

Bilio M, Niermann U (2004) Is the comb jelly to blame for it all? Mnemiopsis leidyi and the ecological concerns about the Caspian Sea. Mar Ecol Prog Ser 269:173-183

Caddy JF (1993) Toward a comparative evaluation of human impacts on fishery ecosystems of enclosed and semienclosed seas. Rev Fish Sci 1:57-95

Harbison GR (2001) The catastrophic invasion of the Black Sea by Mnemiopsis leidyi: Is it only doing what other ctenophores did long ago? In: CIESM 2001. Gelatinous zooplankton outbreaks: theory and practice. CIESM Workshop Series, no. 14, Monaco. Available at: www. ciesm.org/publications/Naples01.pdf

Hinrichsen HH, Böttcher U, Oeberst R, Voss R, Lehmann A (2001) The potential for advective exchange of early life stages between the western and eastern Baltic cod (Gadus morhua L.) stocks. Fish Oceanogr 10:249-258

Horn HS (1966) Measurement of overlap in comparative eco-

Editorial responsibility: Howard Browman (Associate Editorin-Chief), Storebø, Norway logical studies. Am Nat 100:419-424

Javidpour J, Sommer U, Shiganova TA (2006) First record of Mnemiopsis leidyi A. Agassiz 1865 in the Baltic Sea. Aquat Invasions 1:299-302

Kideys AE (2002) Assessing extent and impact of ship-transported alien species in the Black Sea. In: CIESM 2002. Alien marine organisms introduced by ships in the Mediterranean and Black seas. CIESM Workshop Monographs no. 20, Monaco. Available at: www.ciesm.org/ publications/Istanbul102.pdf

Köster FW, Möllmann C, Hinrichsen HH, Wieland K and others (2005) Baltic cod recruitment: the impact of climate variability on key processes. ICES J Mar Sci 62:1408-1425

Kube S, Postel L, Honnef C, Augustin CB (2007) Mnemiopsis leidyi in the Baltic Sea-distribution and overwintering between autumn 2006 and spring 2007. Aquat Invasions 2:137-145

Purcell JE, Shiganova TA, Decker MB, Houde ED (2001) The ctenophore Mnemiopsis in native and exotic habitats: U.S. estuaries versus the Black Sea basin. Hydrobiologia 451:145-176

Shiganova TA, Mirzoyan ZA, Studenikina EA, Volovik SP and others (2001) Population development of the invader ctenophore Mnemiopsis leidyi, in the Black Sea and in other seas of the Mediterranean basin. Mar Biol 139: 431-445

Submitted: September 18, 2007; Accepted: October 18, 2007 Proofs received from author(s): October 25, 2007 